\title{
Fama-French Five-Factor Asset Pricing Model: Testing Validity for Borsa Istanbul and German Stock Exchange
}

\section{Ebubekir MOLLAAHMETOĞLU iD a}

a Istanbul University, Institute of Social Sciences, Money, Capital Markets and Financial Institutions Department, İstanbul, Turkey. ebubekirm@istanbul.edu.tr

\begin{tabular}{|c|c|}
\hline ARTICLE INFO & ABSTRACT \\
\hline $\begin{array}{l}\text { Keywords: } \\
\text { Fama French } \\
\text { Five-Factor Model } \\
\text { BIST30 }\end{array}$ & $\begin{array}{l}\text { Purpose - Fama and French }(2015,2017) \text { proposed to expand Fama and French (1993) three-factor } \\
\text { (portfolio \& the overall market factor, firm size, and book-to-market equity) model building two } \\
\text { new factors (profitability and investment) on, resulting in a five-factor model. This paper } \\
\text { investigates the validity of the five-factor asset-pricing model (FF5F) in BIST30 index in Borsa } \\
\text { Istanbul and DAX30 Index in Germany Stock Exchange. }\end{array}$ \\
\hline $\begin{array}{l}\text { DAX30 } \\
\text { Panel Data }\end{array}$ & $\begin{array}{l}\text { Design/methodology/approach-Static panel data analysis is employed by the fixed-effects within- } \\
\text { group estimator for the period 2009Q2-2018Q4 with two different types of market indices BIST30 } \\
\text { Index and DAX30 Index in order to investigate the validity of the five-factor asset-pricing model } \\
\text { (FF5F). }\end{array}$ \\
\hline $\begin{array}{l}\text { Received } 19 \text { September } 2020 \\
\text { Revised } 10 \text { November } 2020 \\
\text { Accepted } 5 \text { December } 2020\end{array}$ & $\begin{array}{l}\text { Findings - In overall, results demonstrate that there is not enough evidence to suggest the } \\
\text { robustness of the five-factor model may be valid for stocks listed in DAX30 Index but provide } \\
\text { evidence for two-factor model. As for, stocks listed in BIST30, we find enough empirical evidence to } \\
\text { suggest that the four-factor model holds rather than the five-factor model. }\end{array}$ \\
\hline $\begin{array}{l}\text { Article Classification: } \\
\text { Research Article }\end{array}$ & $\begin{array}{l}\text { Discussion-Due to the differentiation of developed markets in terms of higher returns and different } \\
\text { market dynamics it is therefore of utmost importance to assess the applicability of the FF5F model } \\
\text { for developing countries. The findings of the present paper will assist a better evaluation of the risk } \\
\text { factors faced by firms and investors. }\end{array}$ \\
\hline
\end{tabular}

\section{Introduction}

One of the most debatable topics in finance is to determine and measure the relationship the level of risk taken against the expected return to make the best investment decision. Asset pricing studies were followed by many models, from a single-factor model to multi-factor models, such as the Modern Portfolio Theory that was developed by Markowitz (1952), the Capital Asset Pricing Model (CAPM) suggested by Sharpe (1964) and Lintner (1965), Arbitrage Pricing Theory (APT) developed by Ross (1976). Fama and French (2015, 2017) proposed to expand Fama and French (1993) three-factor (portfolio \& the overall market factor, firm size, and book-to-market equity) model adding two new factors (profitability and investment), resulting in a five-factor model (FF5F).

Multi-factor models suggest taking other risk factors into account that companies are faced with many risks, instead of CAPM covering all risk factors as a single factor. These models have been used to explain asset prices as studies show that firm-specific factors are successful in explaining stock returns. However, there are differences between the asset pricing models in terms of the structure and content of the variables considered as risk factors, but main purpose of these models is to explain the risk factors affecting the prices of risky assets and the returns obtained in return for these risk factors. Asset returns can be affected by various risk factors that are responsive to economic developments and macroeconomic variables. Determining the most appropriate asset pricing model in order to control the risk and evaluate the investment, besides the difficulties such as choosing among investment tools and investment amount, will be beneficial in for effective investment decisions for investors and companies.

The FF5F model was initially designed for developed markets and vast literature available addressing the issue of applicability of the model for developed countries. However, due to the considerable difference in 


\section{E. Mollaahmetoğlu 12/4 (2020) 3310-3318}

market dynamics, it is crucial to investigate whether the FF5F model is also applicable in developing countries. Therefore, the objective of this study is to analyze the robustness of the FF5F model in Germany and compare the results with the Turkey stock exchange market, featuring similarities and differences of two financial markets. In this study, as a Bank-Based financial system, portfolios of German Stock exchange represent an advanced financial market, and portfolios of Borsa Istanbul (BIST) represent an emerging financial market that has been analyzed for the period between 2009Q2 and 2018Q4. Hence, the present paper will differ from previous studies by comparing two stock exchanges from different countries featuring the same financial market characteristics and in a different category but in the same period. Furthermore, another contribution of this research to the literature is testing the validity of the FF5F Model by using panel data analysis with a recent dataset. In this respect, this article is expected to contribute to the finance literature and for the effective portfolio management of businesses to assist a better evaluation of the risk factors faced by individual and corporate investors.

The general hypothesis of this paper was designed as follows:

H0: The five-factor asset pricing model does not explain the change in stock returns.

H1: The five-factor asset pricing model explains the change in stock returns.

This paper is divided into four sections; after a brief overview of the subject the second section presents a review of recent literature on the FF5F model, the third section of the analysis consists of research methods, data, and empirical findings. The conclusions are drawn in the final section.

\section{Literature Review}

There has been growing interest in literature after Fama and French $(2015,2017)$ analyzed the five-factor asset pricing model (FF5F) building profitability and investment factors on the three-factor model (FF3F), which consists of market, size and value factors. They found that the FF5F model performs better than the FF3F model.

Over time, literature has been developed the testing validity of the FF5F model for Borsa Istanbul (BIST). Zeren et al. (2019) investigated the validity of FF5F for 18 companies. According to the result of the study covering the period 1995Q1-2017Q3, not enough evidence found for the validity of the FF5F Model Istanbul Stock Market Sustainability Index. Aras et al. (2018) examined the validity of FF5F model by the side of the Capital Asset Pricing Model, FF3F model, and other alternative models for the Turkish stock market with monthly data between January 2005 and June 2017. The study suggests that FF5F model performs better results than other alternative models. Acaravci and Karaomer (2017) tested the validity of FF5F model in Borsa Istanbul (BIST) and according to the results, FF5F model seems to be valid in the BIST and appears to explain variations in excess portfolio returns for the period between July 2005 and June 2016. For testing the validity of the FF5F model for Germany, Dirkx and Peter (2018) used the German stock market's recent monthly data from 2002 to 2017. According to the results, the five-factor model does not add significant explanatory power to the analysis in comparison with the three-factor model. They conclude that the validity of the profitability and investment factors within the context of international asset pricing studies is not verified specifically in the case of the German market. Brückner et al. (2014) examined five data sets that provide Fama and French factors for Germany, in addition to the sets that they had created. They find that the provided time series for the market portfolio and the SMB, HML, and MOM factors differ considerably. Malin and Veeraraghavan (2004) investigated the robustness of the Fama-French multifactor model for equities listed in three European markets. They found evidence of a small firm effect in France and Germany and a big firm effect in the UK and no evidence of a value effect for the markets. They documented a growth effect but rejected the argument that seasonal effects could explain the multifactor model results.

Further research has been carried out and presented on different financial markets. Amézola Berenguer (2017) calculated an FF5F for the European stock market. Consistent with results of Fama and French (2015), value, profitability, and investment risk factors play an important role in assessing the expected return of an asset. This study reports the relationship between the risk factors in North America and the risk factors in Europe. Hu et al. (2019) investigated the size and value factors in the cross-section of returns for the Chinese stock market. They found a significant size effect but no robust value effect. SMB is the strongest factor that illustrate the cross-section of Chinese stock returns. They indicated that results contradicted with several existing 
studies that document a value effect. Vakilifard (2017) compared the FF5F model and the four-factor model of Carhart to explain stock returns of listed companies in the Tehran Stock Exchange. The results show that in the Tehran Stock Exchange, FF3F is credible, while the Carhart four-factor model and FF5F is not valid. Jareño et al. (2018) studied the sensitivity of share prices of Spanish companies included in the IBEX-35 to changes in different explanatory variables, some like market returns, interest rates, and factors proposed by Fama and French $(1993,2015)$ between the period 2000 and 2016. Conducted study affirm that all the considered factors are relevant in general. Furthermore, "market return" and "size" factors show greater explanatory power, together with the "value" factor in the crisis period. Regarding analysis, "Oil and Energy", "Basic Materials, Industry and Construction" and "Financial and Real Estate Services" sectors appear to be highly sensitive to changes in the risk factors included in the asset pricing factor model. Pugdeepunt (2016) has used the FF5F to determine the abnormal return with governance level portfolio scores evaluated by Thai-IOD. The study determined an abnormal return of 9.88 percent annually during the sample period for shows that the poor or unscored governance firms. This is significantly higher than the abnormal return for firms with higher governance scores. Taha and Elgiziry (2016) examined whether earnings-to-price, sales-to price, dividends-toprice, liquidity, and momentum are priced risk factors besides market, size, and book-to-market using 55 companies during the period from July 2005 to June 2013. They proposed an extended FF5F for Egypt, which incorporates market factor, firm size, book-to-market, earnings-to-price, and liquidity, yields better results than the competing models.

The literature review shows that researchers conducted a good number of tests for various financial markets by using different methodologies. However, it is important to investigate whether the FF5F model designed for developed markets is also applicable in developing countries due to the difference in the level of returns and market dynamics.

This section reviews the literature related to models revealing what explains the change in stock returns, but also large number of existing empirical studies in the broader literature, such as Ludwig and Sløk (2004), Şengün and Amanov (2019), have examined the relationship between asset price and macroeconomic and financial variables.

\section{Methodology}

Panel data analyses are estimated by different techniques according to the length of the time series, size of unit time series, and various assumptions. Regression models based on panel data analyses are referred to as panel regression models. Panel data models are separable two principal groups. One is named dynamic where the past values of the variables included in the models. The other one is the static panel data model where past values of the variables are not included that is used in the study encompassing several different linear models according to unobserved heterogeneity such as pooled OLS, fixed-effects (or fixed parameters), and randomeffects models (random variables) (Tatoğlu, 2012). Panel data analyses have several advantages as it combines cross-sectional or time-series data but it poses also a number of challenges. The principal limitation of using panel data is the difficulty of compiling the values of different units for the same variable and for the same period. As an advantage of panel data well known reducing the multi-co-linearity phenomenon of the variables, increasing the number of freedom levels and, the power of tests. (Cerna et al., 2008). In case of equality between observations of each unit in regard to the number of time series is named a balanced panel and if time-series have some missed observations, it is named an unbalanced panel. Observations of panel data have leastways two format; one is a cross-sectional format denoted as $i$ representing the companies, individuals and countries, etc., and the other is time-series format denoted as $t$. in the Equation (1) (Baltagi, 2015).

$$
Y_{i t}=\beta_{0 i t}+\beta_{1 i t} X_{1 i t}+\beta_{2 i t} X_{2 i t}+\ldots+\beta_{k i t} X_{k i t}+u_{i t} \quad \mathrm{i}=1, \ldots, \mathrm{N} \quad \mathrm{t}=1, \ldots, \mathrm{T}
$$

\subsection{Sample, Data Collection and Variables}

The sample covers a quarterly unbalanced panel dataset over the period 2009Q2-2018Q4. The dataset contains 23 listed companies in BIST30 index and 26 listed companies in DAX30 index, yet excluding financial companies (Fama and French, 1993) and the companies whose data is unavailable. Data was collected for BIST30 from Public Disclosure Platform (Provided by the website: www.kap.org.tr) and from Thomson Reuters EIKON for DAX30. 
The average monthly cost of internal borrowing (\%), provided by the Republic of Turkey Prime Ministry Undersecretariat of Treasury and Finance, and monthly EURIBOR data provided by the Deutsche Bundesbank (BBK01.SU0310) (Brückner et al., 2014) is used as a proxy for a risk-free interest rate. Table.1 lists the variables with definitions and summary statistics.

Table.1: Summary Statistics

\begin{tabular}{llcccccccc}
\hline Variables & Definiton & Mean & $\begin{array}{c}\text { Std. } \\
\text { Dev. }\end{array}$ & \multicolumn{1}{c}{ Min. } & Max. & Mean & $\begin{array}{c}\text { Std. } \\
\text { Dev. }\end{array}$ & Min. & Max. \\
\hline \hline & \multicolumn{6}{c}{ DAX30 } & & \multicolumn{4}{c}{ BIST30 } \\
\hline $\mathrm{R}_{\mathrm{it}}-\mathrm{R}_{\mathrm{ft}}$ & $\begin{array}{l}\text { Company's } \\
\text { risk premium }\end{array}$ & 0.1504 & 0.1709 & -1.9458 & 2.3221 & 0.0207 & 0.1769 & -0.6318 & 0.8281 \\
\hline $\mathrm{R}_{\mathrm{mt}}-\mathrm{R}_{\mathrm{ft}}$ & $\begin{array}{l}\text { Market Risk } \\
\text { premium }\end{array}$ & 0.0064 & 0.1443 & -0.4941 & 0.2190 & -0.0343 & 0.0173 & -0.0725 & 0.0235 \\
\hline $\mathrm{SMB}_{\mathrm{t}}$ & Size & 1.6935 & 0.3771 & 0.3609 & 2.3942 & 0.0692 & 0.1687 & -0.3676 & 0.6539 \\
\hline $\mathrm{HML}_{\mathrm{t}}$ & Value & 0.2250 & 0.3633 & -0.0001 & 2.2524 & 1.0845 & 1.0785 & 0.0671 & 11.0149 \\
\hline $\mathrm{RMW}_{\mathrm{t}}$ & Profitability & 0.1109 & 0.0518 & -0.0377 & 0.3389 & 0.0610 & 0.0738 & -0.1201 & 0.5466 \\
\hline $\mathrm{CMA}_{\mathrm{t}}$ & Investment & -1.3075 & 6.0272 & -45.2158 & 74.9951 & -3.9021 & 7.8212 & -36.7828 & 120.6531 \\
\hline \hline
\end{tabular}

The regression equations for FF5F Models are shown as follows:

$R_{i t}-R_{f t}=a_{i}+b_{i}\left(R_{m t}-R_{f t}\right)+S_{i}\left(S M B_{t}\right)+H_{i}\left(H M L_{t}\right)+R_{i}\left(R M W_{t}\right)+C_{i}\left(C M A_{t}\right)+u_{i t}$

$\mathrm{R}_{\mathrm{it}}-\mathrm{R}_{\mathrm{ft}}$ is return of the share $i$ over the risk free rate at time $t, \mathrm{R}_{\mathrm{mt}}-\mathrm{R}_{\mathrm{ft}}$ is excess return of the market portfolio $i$ over the risk free interest rate at time $t, \mathrm{SMB}_{\mathrm{t}}$ is difference between the returns on portfolios of big and small shares at time $t ; \mathrm{HML}_{\mathrm{t}}$ is difference between the returns on portfolios of low and high Book Value / Market Value (BV/MV) ratio at time; $\mathrm{RMW}_{\mathrm{t}}$ is the difference between the returns on portfolios of robust and weak profitability ratio at time $t$ and $\mathrm{CMA}_{\mathrm{t}}$ is the difference between the returns on portfolios of low and high investment ratio at time $t$. (Pugdeepunt, 2016; Acaravci and Karaomer, 2017).

\subsection{Preliminary Test}

Unit root tests allow analyzing whether the data series are stationary or non-stationary in the panel data. Time series are called a stationary only if the average, variance and variance of a time series do not change through time. Before employing the unit root test, it is necessary to determine the existence of cross-section dependence to decide which unit roots test to use. The existence of cross-section dependency in panel data indicate that second-generation unit root tests can provide a more consistent, efficient, and powerful estimation.

Table.2: Panel Unit Root Test

\begin{tabular}{|c|c|c|c|c|c|c|c|}
\hline & & $\mathrm{R}_{\mathrm{it}}-\mathrm{R}_{\mathrm{ft}}$ & $\mathrm{R}_{\mathrm{mt}}-\mathrm{R}_{\mathrm{ft}}$ & $\mathrm{SMB}_{\mathrm{t}}$ & $\mathrm{HML}_{\mathrm{t}}$ & $\mathrm{RMW}_{\mathrm{t}}$ & $\mathrm{CMA}_{\mathrm{t}}$ \\
\hline \multicolumn{8}{|c|}{ Panel A: Pesaran's Cross-Section Dependence within variables } \\
\hline $\mathrm{DAX} 30$ & CD Statistic & $41.63^{*}$ & $111.37^{*}$ & $56.1^{*}$ & $23.23^{*}$ & $5.4^{*}$ & $12.86^{*}$ \\
\hline BIST30 & CD Statistic & $39.14^{*}$ & $94.23^{*}$ & $72.7^{*}$ & $39.44^{*}$ & $43.12^{*}$ & $24.87^{*}$ \\
\hline \multicolumn{8}{|c|}{ Panel B: Panel Unit Root Test - Im, Pesaran and Shin (CIPS) } \\
\hline DAX30 - Lag (0) & $\begin{array}{l}\text { CIPS } \\
\text { Statistic }^{c}\end{array}$ & $-29.3148^{*}$ & $-15.3187^{*}$ & $-3.7474^{*}$ & $-9.9134^{*}$ & $-3.0317^{*}$ & $-28.4811^{*}$ \\
\hline DAX30 - Lag (1) & $\begin{array}{l}\text { CIPS } \\
\text { Statistic }^{\mathrm{c}}\end{array}$ & $-21.9447^{*}$ & $-3.2218^{*}$ & -1.0443 & $-6.7819^{*}$ & $-4.8994^{*}$ & $-17.4626^{*}$ \\
\hline DAX30 - Lag (2) & $\begin{array}{l}\text { CIPS } \\
\text { Statistic }^{\mathrm{c}}\end{array}$ & $-11.2892^{*}$ & $0.8716^{*}$ & -0.1866 & $-2.5319^{*}$ & $-4.5865^{*}$ & $-14.0205^{*}$ \\
\hline BIST30 - Lag (0) & $\begin{array}{l}\text { CIPS } \\
\text { Statistic }^{c}\end{array}$ & $-21.5866^{*}$ & $-24.3513^{*}$ & $-15.692^{*}$ & $-38.4096^{*}$ & $-13.8243^{*}$ & $-33.7795^{*}$ \\
\hline BIST30 - Lag (1) & $\begin{array}{l}\text { CIPS } \\
\text { Statistic }^{\mathrm{c}}\end{array}$ & $-15.4997^{*}$ & $-16.2635^{*}$ & $-13.3615^{*}$ & $-7.1591^{*}$ & $-13.688^{*}$ & $-17.7928^{*}$ \\
\hline
\end{tabular}


E. Mollaahmetoğlu 12/4 (2020) 3310-3318

\begin{tabular}{|c|c|c|c|c|c|c|c|}
\hline BIST30 - Lag (2) & $\begin{array}{l}\text { CIPS } \\
\text { Statistic }^{\mathrm{c}}\end{array}$ & $-10.7369^{*}$ & $-8.1229^{*}$ & $-11.5358^{*}$ & $-5.5974^{*}$ & $-7.6911^{*}$ & $-12.5952^{*}$ \\
\hline DAX30 - Lag (0) & $\begin{array}{l}\text { CIPS } \\
\text { Statistic }{ }^{\mathrm{c}+\mathrm{t}}\end{array}$ & $-28.6281^{*}$ & $-23.3217^{*}$ & $-2.7291^{*}$ & $-8.5741^{*}$ & -0.8455 & $-27.4551^{*}$ \\
\hline DAX30 - Lag (1) & $\begin{array}{l}\text { CIPS } \\
\text { Statistic }^{c+t}\end{array}$ & $-20.8675^{*}$ & $-9.4876^{*}$ & -0.0005 & $-5.7444^{*}$ & $-3.5871^{*}$ & $-3.5871^{*}$ \\
\hline DAX30 - Lag (2) & $\begin{array}{l}\text { CIPS } \\
\text { Statistic }^{\mathrm{ct}}\end{array}$ & $-9.4098^{*}$ & $-4.0077^{*}$ & 2.7733 & $-7.7856^{*}$ & $-4.3822^{*}$ & $-4.3822^{*}$ \\
\hline BIST30 - Lag (0) & $\begin{array}{l}\text { CIPS } \\
\text { Statistic }^{c+t}\end{array}$ & $-20.5688^{*}$ & $-21.9096^{*}$ & $-4.9686^{*}$ & $-41.0324^{*}$ & $-14.1528^{*}$ & $-33.3961^{*}$ \\
\hline BIST30 - Lag (1) & $\begin{array}{l}\text { CIPS } \\
\text { Statistic }^{\mathrm{ctt}}\end{array}$ & $-13.4825^{*}$ & $-17.1111^{*}$ & $-1.8805^{*}$ & $-7.2153^{*}$ & $-16.1887^{*}$ & $-16.1887^{*}$ \\
\hline BIST30 - Lag (2) & $\begin{array}{l}\text { CIPS } \\
\text { Statistic }^{c+t}\end{array}$ & $-8.3272^{*}$ & $-9.4523^{*}$ & $-0.3838^{*}$ & $-4.6625^{*}$ & $-11.6786^{*}$ & $-11.6786^{*}$ \\
\hline
\end{tabular}

Note: H0: The serial contains unit root and is not stationary and H1: The serial does not contain unit root and is stationary; *** significant at $10 \%,{ }^{* *}$ significant at $5 \%$ and ${ }^{*}$ significant at $1 \%$ level.

Unit root test proposed by Pesaran (2007) for error cross-sectional dependency display correct size and sufficient power even in small samples. As the probability value obtained from the test is less than 0.05 , "crosssection hypothesis" cannot be rejected at 5\% significance level and horizontal. According to the results shown in the Panel A in Table 2, data series indicate the presence of a cross-section dependency.

Im, Pesaran and Shin (2003) proposed a unit root test for panel analysis in case of the presence of cross-section dependence and non-normality. Panel B in Table 2 shows Im, Pesaran and Shin (2003) unit root test results relating to the data series in constant and constant + trend. Test results give mostly an indication of stationarity of variables and cannot strongly reject that all series contain a stationary. Due to powerful results, our analyses continue to using the first difference of SMB and RMW variables. This result shows that the shocks to the SMB and RMW series from the relevant series have not lost their effect immediately.

\subsection{Diagnostic Test}

For estimation of the panel dataset, tests were followed firstly with LR test. Results on the Table 3 and Panel A below, show there is individual or time effects in the model. It is employed to decide whether model is appropriate for pooled OLS and fixed effects model or random effects model. According to LR Test result in the first column, retesting individual or time effect separately, it has been seen there is individual or time effects for all models. As we separately test the individual and time effect; second row shows that there is no individual effect and the third row, LR test result, shows that there is time effect. As shown on the Panel A, it is concluded that models does not contain individual effect, but rather time effect in the models.

Hausman (1978) test allows choosing between fixed-effects and random-effects models. According to the Hausman test Fixed Effect Model is appropriate if $H_{0}: E\left(v_{i} \mid \bar{x}_{i, t}\right)=0$, Random Effect Model is appropriate if $H_{1}: E\left(v_{i} \mid \bar{x}_{i, t}\right) \neq 0$. Results, in the Table 3, Panel B shows that that fixed-effects model is acceptable for all models at 5 percent significance level.

Test for heteroscedasticity statistics reject the null hypothesis homoscedasticity and resulted heteroscedasticity (H0: If Prob > chi2 bigger 5\% = Homoscedasticity, H1: If Prob > chi2 less than 5\% = Heteroscedasticity). DW and Baltagi-Wu LBI test (Autocorrelation test) statistics reject the null hypothesis of no first-order serial correlation. Therewithal; DW critical values; $\mathrm{d}<2$ shows positive serial correlation. Pesaran's test strongly reject the null hypothesis of no cross-sectional dependence at the $1 \%$ level of significance. These results produce enough evidence for the existence of cross-sectional dependency between cross sectional units. Four tests are tabulated, Table 3, Panel B, as follows: 
Table.3: Individual and/or Time Effects and Diagnostic Test Results

\begin{tabular}{|c|c|c|c|c|c|}
\hline & & $\begin{array}{c}\text { BIST30 } \\
\text { FF5F } \\
\end{array}$ & $\begin{array}{c}\text { DAX30 } \\
\text { FF5F } \\
\end{array}$ & $\begin{array}{c}\text { BIST30 } \\
\text { FF4F } \\
\end{array}$ & $\begin{array}{c}\text { DAX30 } \\
\text { FF2F }\end{array}$ \\
\hline \multicolumn{6}{|c|}{ Panel A: Individual and/or Time Effects Test Results } \\
\hline Individual and Time Effects & LR & $\begin{array}{l}\text { P-value } \\
(0.0000)\end{array}$ & $\begin{array}{l}\text { P-value } \\
(0.0000)\end{array}$ & $\begin{array}{l}\text { P-value } \\
(0.0000)\end{array}$ & $\begin{array}{l}\text { P-value } \\
(0.0000)\end{array}$ \\
\hline Individual Effect & $\mathrm{F}$ & $\begin{array}{l}\text { P-value } \\
(0.4658)\end{array}$ & $\begin{array}{l}\text { P-value } \\
(0.9900)\end{array}$ & $\begin{array}{l}\text { P-value } \\
(0.3729)\end{array}$ & $\begin{array}{l}\text { P-value } \\
(0.1000)\end{array}$ \\
\hline Time Effect & LR & $\begin{array}{l}\text { P-value } \\
(0.0000) \\
\end{array}$ & $\begin{array}{l}\text { P-value } \\
(0.0000)\end{array}$ & $\begin{array}{l}\text { P-value } \\
(0.0000)\end{array}$ & $\begin{array}{l}\text { P-value } \\
(0.0000)\end{array}$ \\
\hline \multicolumn{6}{|c|}{ Panel B: Diagnostic Test Results } \\
\hline Test for Random or Fixed Effects & Hausman & $14.38^{* *}$ & $127.97^{*}$ & $14.17^{*}$ & $128.42^{*}$ \\
\hline Test for Heteroscedasticity & Wald & $9837.49^{*}$ & $1164.65^{*}$ & $9792.98^{*}$ & $1534.85^{*}$ \\
\hline Autocorrelation test & $\begin{array}{l}\text { BNF-Durbin- } \\
\text { Watson Test and } \\
\text { Baltagi-Wu's LBI }\end{array}$ & $\begin{array}{l}1.8550 \\
1.9571\end{array}$ & $\begin{array}{c}1.8549 \\
1.993\end{array}$ & $\begin{array}{l}1.8452 \\
1.9503\end{array}$ & $\begin{array}{l}1.8549 \\
1.8549\end{array}$ \\
\hline Test for Cross Sectional Dep. & Pesaran & $18.679^{*}$ & $33.348^{*}$ & $19.551^{*}$ & $33.348^{*}$ \\
\hline
\end{tabular}

${ }^{* * *}$ significant at $10 \%,{ }^{* *}$ significant at $5 \%$ and ${ }^{*}$ significant at $1 \%$ level.

As a results of diagnostic test; Hausman Test, Modified Wald test for group-wise Heteroscedasticity, Pesaran test for cross sectional dependency and BNF-Durbin-Watson Test and Baltagi-Wu's LBI for autocorrelation call for the fixed effects regression with Driscoll and Kraay standard errors.

\subsection{Findings}

Driscoll and Kraay (1998) presents a nonparametric covariance matrix estimator. This estimator is selected to reflect the feasible problems of models that are heteroscedasticity, autocorrelated error structures, and possible correlation in the panel dataset. The robust estimation of a fixed-effects model with Driscoll and Kraay standard errors, are presented in Table 4.

Table 4: Panel Regression with Driscoll-Kraay standard errors

\begin{tabular}{|c|c|c|c|c|}
\hline $\mathrm{R}_{\mathrm{it}}-\mathrm{R}_{\mathrm{ft}}$ & BIST30 FF5F & DAX30 FF5F & BIST30 FF4F & DAX30 FF2F \\
\hline $\mathrm{R}_{\mathrm{mt}}-\mathrm{R}_{\mathrm{ft}}$ & $\begin{array}{l}0.7810^{* *} \\
(0.4166)\end{array}$ & $\begin{array}{c}0.2154 \\
(0.1336)\end{array}$ & $\begin{array}{l}0.8103^{* *} \\
(0.4282)\end{array}$ & $\begin{array}{l}0.2894^{*} \\
(0.1005)\end{array}$ \\
\hline $\mathrm{SMB}_{\mathrm{t}}$ & $\begin{array}{l}0.6801^{*} \\
(0.0402)\end{array}$ & $\begin{array}{c}0.1251 \\
(0.1443)\end{array}$ & $\begin{array}{l}0.6774^{*} \\
(0.0405)\end{array}$ & 1 \\
\hline $\mathrm{HML}_{\mathrm{t}}$ & $\begin{array}{l}-0.0220^{* *} \\
(0.0076)\end{array}$ & $\begin{array}{l}0.5368^{* *} \\
(0.2225)\end{array}$ & $\begin{array}{l}-0.0224^{* *} \\
(0.0044)\end{array}$ & $\begin{array}{l}0.4932^{* *} \\
(0.1797) \\
\end{array}$ \\
\hline $\mathrm{RMW}_{\mathrm{t}}$ & $\begin{array}{l}0.3373^{* *} \\
(0.1434)\end{array}$ & $\begin{array}{l}-0.3051 \\
(0.2463)\end{array}$ & $\begin{array}{l}0.3423^{*} \\
(0.1465)\end{array}$ & 10 \\
\hline $\mathrm{CMA}_{\mathrm{t}}$ & $\begin{array}{r}-0.0008 \\
(0.0010) \\
\end{array}$ & $\begin{array}{l}-0.0006 \\
(0.0007) \\
\end{array}$ & - & - \\
\hline Constant & $\begin{array}{l}-0.0038 \\
(0.0197)\end{array}$ & $\begin{array}{l}-0.1579 \\
(0.3038)\end{array}$ & $\begin{array}{r}0.0085 \\
(0.0209)\end{array}$ & $\begin{array}{c}0.0346 \\
(0.0407)\end{array}$ \\
\hline F Test & 0.0000 & 0.0002 & 0.0000 & 0.0024 \\
\hline $\begin{array}{l}\text { Number of Obs. / } \\
\text { Groups }\end{array}$ & $847 / 23$ & $991 / 26$ & $847 / 23$ & $991 / 26$ \\
\hline R-squared & 0.41 & 0.19 & 0.39 & 0.18 \\
\hline
\end{tabular}

${ }^{* * *}$ significant at $10 \%,{ }^{* *}$ significant at $5 \%$ and ${ }^{*}$ significant at $1 \%$ level, $t$-statistics are given in parentheses

Our implementation of the Fama-French five-factor model to the BIST30 FF5F and DAX30 FF5F shown in the first and second columns of Table 4. According to the result of the model; factors are not significant at significance level in DAX30-FF5F model except value of companies $\left(\mathrm{HML}_{t}\right)$ and investment factor $\left(\mathrm{CMA}_{t}\right)$ is 
not significant in BIST30-FF5F model. This outcome makes the BIST30 FF5F and DAX30 FF5F invalid due to insignificant factors (or parameters) and not respond to the condition of the Five Factor Asset Pricing Model.

We re-estimate models parameters applying the Driscoll and Kraay (1998) standard errors according to the preliminary and diagnostic tests. According to the results of the model for BIST30-FF5F and DAX30-FF5F; factors (or parameters) that are statistically significant were chosen for new models and re-estimated. These re-estimated models have been named BIST30-FF4F and DAX30-FF2F and provided in Table 4; overall regression results are significant at 1 percent significance level (F test) and the R-squared coefficient explains about $39 \%$ and $17 \%$ of the Company's risk premium in both model.

BIST30-FF4F and DAX30-FF2F model indicates that higher market risk premium $\left(\mathrm{R}_{\mathrm{mt}}-\mathrm{R}_{\mathrm{ft}}\right)$ implies a higher risk premium for the company. BIST30-FF4F indicates that higher market value $\left(\mathrm{SMB}_{\mathrm{t}}\right)$ implies a higher risk premium for the company. BIST30-FF4F indicates that book-to-market ratio $\left(\mathrm{HML}_{\mathrm{t}}\right)$ implies a lower risk premium for the company, but DAX30-FF2F model indicates that higher market value $\left(\mathrm{HML}_{\mathrm{t}}\right)$ implies a higher risk premium for the company. Finally, BIST30-FF4F indicates that expected earnings (profitability) ( $\mathrm{RMW}_{\mathrm{t}}$ ) imply a higher risk premium for the company.

\section{Discussion and Conclusion}

Asset pricing models are followed by many models such as CAPM, Arbitrage Pricing Model (APM), FamaFrench 3 Factor Model (FF3F), Fama-French 4 Factor Model (FF4F), and recently introduced Fama-French 5 Factor Model (FF5F). The literature review shows that CAPM, FF3F, and FF4F have been tested by various researchers for different financial markets by using various methodologies. Before the five-factor Asset Pricing Model, three-factor Asset Pricing Model was found to be successful in explaining stock returns according to the many studies (Malin and Veeraraghavan, 2004; Janero, 2008) and on the other hand, the models are also criticized in many studies as well (Chen and Zhang, 2009; Tauscher and Wallmeier, 2016).

This study uses panel data analysis to determine the validity of the five-factor asset-pricing model (FF5F) for BIST30 index in Istanbul Stock Exchange and DAX30 in Germany Stock Exchange for the period of 2009Q22018Q4. BIST30-FF4F and DAX30-FF2F model indicates that higher market risk premium $\left(\mathrm{R}_{\mathrm{it}}-\mathrm{R}_{\mathrm{ft}}\right)$ imply higher risk premium. BIST30-FF4F indicates that higher market value $\left(\mathrm{SMB}_{\mathrm{t}}\right)$ imply a higher risk premium for the company. The findings are directly in line with previous findings of Fama and French (2015) and Charitou and Constantinidis (2004), Zeren et al. (2019). Contrary to the findings of Fama and French (2015), BIST30-FF4F indicates that higher market value $\left(\mathrm{HML}_{\mathrm{t}}\right)$ implies lower risk premium for the company, however in line with the study of, Zeren et al. (2019). DAX30-FF2F model indicates that higher book-to-market ratio (HMLt) implies a higher risk premium for the company and its effect stronger than the market risk premium. The findings are directly in line with previous findings of Fama and French (2015), Charitou and Constantinidis (2004), and, Malin and Veeraraghavan (2004) for high book-to-market firms. BIST30-FF4F indicates that expected earnings (profitability) $\left(\mathrm{RMW}_{\mathrm{t}}\right)$ implies a higher risk premium for the company. The findings are directly in line with previous findings of Fama and French (2015), Lin (2017) and Zeren et al. (2019). Investment factor $\left(\mathrm{CMA}_{\mathrm{t}}\right)$, is one of the additional factors (profitability and investments) to FamaFrench three-factor models and is not statistically significant in all estimated models. Dirkx and Peter (2018) also find that the investment factor is not supported by their implementation of the Fama-French five-factor model to the German stock market.

Considering all these results, there is not enough evidence to suggest that the five-factor model may be valid for stocks listed in DAX30 but provide evidence for the two-factor model. This implies that it would be beneficial to create portfolios from companies that have high market premium and high BV / MV ratio and trading in DAX 30 index. As for, stocks listed in BIST30, we find enough evidence to suggest that the fourfactor model holds rather than the five-factor model. This implies that it would be beneficial to create portfolios from companies, have a high market value, high market premium, and high profitability, but small BV / MV ratio and listed in BIST30 index. There has been long interest, hence expanding literature on asset price models. The findings of the present paper may be useful for a better evaluation of the risk factors faced by firms and investors. 


\section{References}

Acaravci K.S. and Karaomer, Y. (2017). Fama-French Five Factor Model: Evidence from Turkey. International Journal of Economics and Financial Issues, 7(6), 130.

Aras, G., Çam, İ., Zavalsız, B. and Keskin, S. (2018). Fama-French Çok Faktör Varlık Fiyatlama Modellerinin Performanslarının Karşılaştırılması: Borsa İstanbul Üzerine Bir Uygulama. Journal of Istanbul University Journal of the School of Business Administration, 47(2).

Amézola Berenguer, L. (2017). A 5-factor Risk Model for European Stocks (Master's Thesis, Universitat Politècnica de Catalunya).

Baltagi, B. H. (Ed.). (2015). The Oxford Handbook of Panel Data. Oxford Handbooks.

Brückner, R., Lehmann, P., Schmidt, M. H. and Stehle, R. (2014). Fama/French factors for Germany: Which set is best, Working paper, Humboldt University Berlin.

Cerna, S., Donath, L. and Şeulean, V. (2008). Stabilitatea Financiară. Editura Universităţii de Vest. Timişoara.

Charitou, A. and Constantinidis, E. (2004): Size and Book-to-Market Factors in Earnings and Stock Returns: Empirical Evidence for Japan. Working paper, University of Cyprus.

Chen, L. and Zhang, L. (2009). An Equilibrium Three-Factor Model. NBER Working Paper, 13282.

Driscoll, J. C. and Kraay, A. C. (1998). Consistent Covariance Matrix Estimation with Spatially Dependent Panel Data. Review of Economics and Statistics, 80(4), 549-560.

Dirkx, P. and Peter, F. (2018). Implementing the Fama-French Five-Factor Model for the German Stock Market. Available at SSRN 3300642. doi:10.2139/ssrn.3300642

Fama, E. F. and French, K. R. (1993). Common Risk Factors in the Returns on Stocks and Bonds. Journal of Financial Economics, 33(1), 3-56.

Fama, E. F. and French, K. R. (2015). A Five-Factor Asset Pricing Model. Journal of Financial Economics, 116(1), $1-22$.

Fama, E. F. and French, K. R. (2017). International Tests of a Five-Factor Asset Pricing Model. Journal of Financial Economics, 123(3), 441-463.

Hausman, J. A. (1978). Specification Tests in Econometrics. Econometrica: Journal of the Econometric Society, 12511271.

Hu, G. X., Chen, C., Shao, Y. and Wang, J. (2019), Fama-French in China: Size and Value Factors in Chinese Stock Returns. International Review of Finance, 19: 3-44. doi:10.1111/irfi.12177

Im, K. S., Pesaran, M. H. and Shin, Y. (2003). Testing for Unit Roots in Heterogeneous Panels. Journal of Econometrics, 115(1), 53-74.

Jareño, F., M. González, M. Tolentino and S. Rodríguez. (2018). Interest Rate Sensitivity of Spanish Companies. An Extension of the Fama and French Five-Factor Model. Acta Oeconomica 68 (4), 617-638. doi:10.1556/032.2018.68.4.7.

Janero, F. (2008). Spanish Stock Market Sensitivity to Real Interest and Inflation Rates: An Extension of the Stone Two-Factor Model with Factors of the Fama and French Three Factor Model. Applied Economics, 40, 3159-3171.

Lintner, J. (1965). Security Prices, Risk, and Maximal Gains from Diversification. The Journal of Finance, 20(4), 587-615.

Lin, Q. (2017). Noisy Prices and the Fama-French Five-Factor Asset Pricing Model in China. Emerging Markets Review, 31, 141-163

Ludwig, A. and Sløk, T. (2004). The Relationship between Stock Prices, House Prices and Consumption in OECD Countries. Topics in Macroeconomics, 4(1). 
E. Mollaahmetoğlu 12/4 (2020) 3310-3318

Malin, M. and Veeraraghavan, M. (2004). On the Robustness of the Fama and French Multifactor Model: Evidence from France, Germany, and the United Kingdom. International Journal of Business and Economics, 3(2), 155.

Markowitz, H. (1952). Portfolio Selection. The Journal of Finance, 7(1), 77-91.

Pesaran, M. H. (2007). A Simple Panel Unit Root Test in the Presence of Cross-Section Dependence. Journal of Applied Econometrics, 22(2), 265-312.

Pugdeepunt, M. V. (2016). Corporate Governance and Fama-French Five-Factor: Evidence from Stock Exchange of Thailand (Doctoral Dissertation, Thammasat University).

Ross, S. A. (1976). The Arbitrage Theory of Capital Asset Pricing. Journal of Economic Theory, 13.

Sharpe, W. F. (1964). Capital Asset Prices: A theory of Market Equilibrium under Conditions of Risk. The Journal of Finance, 19(3), 425-442.

Şengün, G. and Amanov, A. (2019). Asset Price Channel: Evidence from Turkey. Doğuş Üniversitesi Dergisi, 20(2), 89-103.

Taha, R. and Elgiziry, K. (2016). A Five-Factor Asset Pricing Model: Empirical Evidence from Egypt. International Journal of Business, 21(4), 342.

Tatoğlu, F., Y. (2012), Panel Veri Ekonometrisi, Beta Yayınevi. ISBN 978-605-333-003-5

Tauscher, K. and Wallmeier, M. (2016). Portfolio Overlapping Bias in Tests of the Fama-French Three-Factor Model. European Financial Management, 22(3), 367-393.

Vakilifard, H. R., Badrian, E. and Ebrahimi, M. (2017). A Comparison between Fama-French Five Factor Model and Carhart Four-Factor Model in Explaining the Stock Return of Companies Listed in the Tehran Stock Exchange. Journal of Asset Management and Financing, 5(1), 17-29.

Zeren, F., Yilmaz, T. and Belke, M. (2019). Testing the Validity of Fama French Five Factor Asset Pricing Model: Evidence from Turkey. Financial Studies, 97. 